Prekariat - perspektywa katolickiej nauki społecznej, red. J. Mazur OSPPE, ks. Ł. Marczak, Kraków 2017 (Spotkania Naukowe Wykładowców Katolickiej Nauki Społecznej, XIII), s. 49-74.

DOI: http://dx.doi.org/10.15633/9788374385985.04

ks. Andrzej Zwoliński

Uniwersytet Papieski Jana Pawła II w Krakowie

\title{
Pracownik jako ofiara niesprawiedliwości w ujęciu katolickiej nauki społecznej*
}

Papież Jan Paweł II, wskazując na problem własności, ukazał jego ważność dla budowania ludzkiej odpowiedzialności za siebie i innych. Podkreśla, że pierwotnie źródłem własności był dar natury - urodzajna ziemia, która wymagała udoskonalania przez pracę. Później własnością był kapitał przedsiębiorstwa, lecz coraz większego znaczenia nabierał w nim wykwalifikowany pracownik, który świadczył coraz bardziej wyspecjalizowaną pracę. Obecnie zaś wskazać trzeba na człowieka jako podmiot pracy, najważniejsze źródło własności. W encyklice Centesimus annus (1991) Jan Paweł II podjął analizę złożonej struktury „obecności” człowieka w pracy (CA 30-43). Stwierdził, że inteligencja człowieka pozwala mu odkrywać możliwości produkcyjne oraz różnorakie sposoby zaspokojenia własnych potrzeb. Zdyscyplinowana i solidarna praca wymaga wypracowania takich cech, jak: rzetelność, pracowitość, roztropność, męstwo i wierność w dotrzymywaniu umowy ${ }^{1}$.

* Tekst zawiera treści, które po części wskazują na zjawisko prekaryzmu, ujawniające się szczególnie wtedy, gdy pracownik występuje w roli ofiary niesprawiedliwych warunków pracy i płacy, stając się prekariuszem - przyp. red. 1 Por. W. Piwowarski, Własność w społecznym nauczaniu Kościoła, „Zeszyty Społeczne KIK" 4 (1996) nr 4, s. 5. 


\section{Okradanie pracownika}

W historii ludzie pracy byli wykorzystywani na różne sposoby. Jednym ze sposobów wyzysku i niesprawiedliwości wobec nich było zatrzymanie zapłaty za wykonaną pracę. Już w Starym Testamencie jest sformułowane oczywiste pouczenie: „Pracownikom nie odmawiaj zapłaty, gdy masz możność działania. Nie mów bliźniemu: «Idź sobie, przyjdź później, dam jutro» - gdy możesz dać zaraz” (Prz 3, 27); „Nie będziesz niesprawiedliwie gnębił najemnika ubogiego i nędznego, czy to będzie brat twój, czy obcy, o ile jest w twoim kraju, w twoich murach. Tegoż dnia oddasz mu zapłatę, nie pozwolisz zajść nad nią słońcu, gdyż jest on biedny i całym sercem jej pragnie; by nie wzywał Pana przeciw tobie, a to by cię obciążało grzechem” (Pwt 24, 14-15); „Oto woła zapłata robotników, żniwiarzy pól waszych, którą otrzymaliście, a krzyk ich doszedł do uszu Pana Zastępów [...]. Potępiliście i zabili sprawiedliwego" (Jk 5, 4-6). Umówiona zapłata była nadzieją pracujących, a pozbawienie jej jest atakiem na życie.

Z początkami wymiany wiąże się również obyczaj dzielenia się dobrami podczas trudnych sytuacji losowych - który występował w różnych kulturach - i jest najbardziej zrozumiały, gdyż w ten sposób ofiarodawca zabezpiecza się na przyszłość. Ten, kto potrzebuje pomocy obecnie, otrzymuje ją od kogoś, kto może się znaleźć w podobnej potrzebie jutro. A to już początek nowych więzi społecznych, u których źródeł jest wzajemna wymiana dóbr i usług.

W historycznym rozwoju kultury znane były różnego rodzaju formy niesienia pomocy, ale też i kradzieży, wzbogacania się czyimś kosztem, prowadzenia egoistycznego rozrachunku z korzystania $z$ dóbr materialnych. W klasycznym rozumieniu kradzieży św. Tomasz z Akwinu wyróżnia trzy jej istotne elementy:

Po pierwsze, przywłaszczenie sobie cudzej rzeczy, gdyż to sprzeciwia się sprawiedliwości, która każdemu oddaje to, co się mu należy. Po drugie, posiadanie cudzej rzeczy, gdyż to 
odróżnia kradzież od grzechów przeciw osobie, jak zabójstwo lub okaleczenie. Jeśli bowiem ktoś zabiera komuś nie to, co posiada, ale to, co stanowi jego część, np. gdy utnie jakiś członek ciała, albo gdy weźmie mu osobę, która z nim jest związana, np. córkę lub żonę, wówczas nie będzie to kradzież we właściwym znaczeniu. Po trzecie, potajemność zabrania, gdyż ta różnica uzupełnia pojęcie kradzieży. Tak więc kradzież polega na potajemnym zabraniu cudzej rzeczy² .

Kradzież ze swej istoty narusza sprawiedliwość społeczną, wymienną i rozdzielczą. Wielkość zła zależy od krzywdy wyrządzonej przez kradzież drugiemu człowiekowi. Kradzież nawet małej rzeczy człowiekowi ubogiemu jest więc o wiele większą krzywdą niż np. potajemne zabranie takiej samej rzeczy komuś bardzo bogatemu. W swej istocie siódme przykazanie Dekalogu jest wezwaniem do respektowania wolności i godności człowieka. Człowiek jest nietykalny, a tej zasady nie może podważać nikt i nic, także nauka, technika, polityka. Wymaga to relacji społecznych, które cechuje sprawiedliwość i miłość ${ }^{3}$.

Kradzież nie dotyczy jedynie relacji indywidualnych, chociaż najczęściej z takimi jest kojarzona. Czytamy w Księdze Kapłańskiej wezwanie do zachowania normy prawnej:

Nie będziecie kraść, nie będziecie kłamać, nie będziecie oszukiwać jeden drugiego [...]. Nie będziesz uciskał bliźniego, nie będziesz go wyzyskiwał. Zapłata najemnika nie będzie pozostawać $\mathrm{w}$ twoim domu przez noc do poranka [...]. Nie będziecie wydawać niesprawiedliwych wyroków. Nie będziesz stronniczym na korzyść ubogiego, ani nie będziesz miał

2 Św. Tomasz z Akwinu, Suma teologiczna, t. 18 Sprawiedliwość, tł. F. W. Bednarski, London 1970, s. 134-135.

3 L. Balter, Dobroczyńcy i złodzieje, „Communio” 109 (1999) nr 1, s. 3-15; S. Pezzotta, Siódme: nie kradnij, „Społeczeństwo” (2008) nr 2, s. 251-253. 
względów dla bogatego. Sprawiedliwie będziesz sądził bliźniego (Kpł 19, 11-15).

Chociaż zasadniczo słowa te odnoszą się do relacji międzyosobowych, to mówią też o strukturze społecznej, której fundamentem powinna być sprawiedliwość. Zło kradzieży polega na wykroczeniu przeciw sprawiedliwości społecznej, które niszczy istniejące relacje i struktury. Jest zdradą miłości bliźniego i zanegowaniem solidarności. Św. Klemens Aleksandryjski wyraził to dobitnie słowami: „Bóg uczynił rzeczy dla wszystkich; z tej przyczyny wszystkie rzeczy są wspólne. Bóg pozwolił nam tylko na używanie tych rzeczy"4.

\section{Chrześcijaństwo o okradaniu pracownika}

Według św. Tomasza z Akwinu sprawiedliwość w społeczności jest zachowana, gdy są w niej ustanowione i właściwie funkcjonują trzy podstawowe struktury społeczne: relacje między jednostkami („ordo partium ad partes”); stosunek całości społeczeństwa do jednostki („ordo totius ad partes”) oraz stosunek jednostki do całej społeczności („ordo partium ad totum”). Gdy któraś z tych struktur działa źle, trzeba całą społeczność uznać za niesprawiedliwą. A wszelkie wykroczenia przeciwko sprawiedliwości wymagają specyficznej restytucji - wyrównania szkody samej osobie poszkodowanej lub jej spadkobiercom. W tym obszarze rozważań moralnych pojawia się pojęcie tzw. kradzieży pozornej, gdy następuje przywłaszczenie sobie cudzych dóbr, które jednak nie jest kradzieżą. Zachodzi ona w dwóch przypadkach: przywłaszczenia sobie cudzej rzeczy w sytuacji krańcowej potrzeby oraz potajemnego wyrównywania sobie wyrządzonej przez

4 Cyt. za: F. Charrier, Kradzież indywidualna i społeczna, „Communio” 109 (1999) nr 1, s. 18. 
kogoś krzywdy. Konstytucja duszpasterska o Kościele w świecie współczesnym Gaudium et spes przypomina: „Kto natomiast byłby w skrajnej potrzebie, ma prawo z cudzego majątku wziąć dla siebie rzeczy konieczne do życia" (KDK 69). Zabranie dobra prywatnego lub wspólnego dla ratowania życia jest usprawiedliwione przez charakter stworzonego i powszechnego przeznaczenia dóbr tej ziemi. Muszą być spełnione odpowiednie warunki: jest to forma ostateczna, po którą sięga się po wykorzystaniu innych możliwości wyjścia $\mathrm{z}$ takiej sytuacji; zabór własności możliwy jest tylko w ilości koniecznej do zaradzenia krańcowej sytuacji; takie przywłaszczenie nie może wprowadzać osoby, której zabiera się dane dobro, w podobną sytuację. Zabór dla wyrównania krzywdy zachodzi w sytuacji, gdy usprawiedliwia to prawo do obrony człowieka przed krzywdą. Musi być spełniony szereg warunków: musi zachodzić krzywda realna, a nie domniemana; jest to sposób ostateczny, gdy wyczerpano inne możliwości dochodzenia sprawiedliwości; wykluczone jest wyrządzanie jakiejkolwiek krzywdy osobom trzecim (np. możliwość ich fałszywego posądzenia); wyrównanie szkody może być tylko do wysokości wyrządzonej szkody, bez możliwości przekroczenia jej wielkości; wyrównanie krzywdy nie może wprowadzać osoby, od której chciałoby się odebrać swoją własność, w stan krańcowej potrzeby. Sytuacja ta jest dyskusyjna w przypadku możliwości wyrównania sobie krzywdy wyrządzonej pracownikowi przez pracodawcę. Najwłaściwszą bowiem drogą jest dochodzenie swych praw przez renegocjację zawartych umów czy spory zbiorowe, także za pomocą nacisków ze strony związków zawodowych. Potajemne odbieranie należności może prowadzić do rozszerzenia własnego sumienia, subiektywnego i czasem domniemanego powiększania własnej krzywdy. Nie zmienia to jednak faktu, że, jak to przypomniała Kongregacja Nauki Wiara w Instrukcji o chrześcijańskiej wolności i wyzwoleniu: „Rażące niesprawiedliwości, nierówności i ucisk wszelkiego rodzaju, uderzające dzisiaj w miliony mężczyzn i kobiet, pozostają w jawnej sprzeczności z Ewangelią 
Chrystusa i nie mogą pozostawić w spokoju sumienia żadnego chrześcijanina" (nr 57)

W relacji pracownik - pracodawca kradzież i wyrządzanie krzywdy może mieć bardzo różną postać. Efektem jest zwykle niesprawiedliwe zaniżanie pensji, czyli płacy za wykonaną pracę. Najczęściej tłumaczenie pracodawcy jest demagogiczne, wiąże się z ekonomicznym fałszem. Przykładem może być twierdzenie o wysokich kosztach pracy, które próbuje się obniżać przez zmniejszenie płac. Niekiedy ta obniżka jest ukryta: w dążeniu do oszczędzania łączy się stanowiska i poszerza zakres obowiązków; w ten sposób firma wymaga więcej pracy za to samo wynagrodzenie $^{6}$. Efektem jest wzrost produkcji przy ukrytej obniżce płac. Jak wyliczył amerykański ekonomista Lester C. Thurow, od roku 1973 do 1994 realny produkt krajowy brutto USA na mieszkańca zwiększył się o 33 proc., ale przeciętna płaca tygodniowa robotników i urzędników na niekierowniczych stanowiskach spadła w tym czasie o 19 proc.. W roku 1994 płace tej grupy były na tym samym poziomie co w końcu lat 50 . XX wieku. Tłumaczy to wzrost liczby tzw. „working poor” („pracujący biedacy”), tzn. grupy ludzi, którzy pomimo stałego zatrudnienia żyją poniżej granicy ubóstwa ${ }^{7}$. Efektem jest narastająca w społeczeństwie dysproporcja płac, która stwarza i utrwala przepaść ekonomiczną pomiędzy poszczególnymi grupami społecznymi, rodząc poczucie niesprawiedliwości.

5 Por. S. Skobel, Kradziė̇ rzeczywista a kradzież pozorna, "Communio" 109 (1999) nr 1, s. 24-31; P. Góralczyk, „Kradzież pozorna” w kontekście wielkich niesprawiedliwości społecznych, „Communio” 109 (1999) nr 1, s. $57-72$.

6 J. Żyżyński, Mitologia wysokich kosztów pracy, „Nasz Dziennik” 7 XII 2001, s. 11; D. Mattioli, Firmy wymagaja więcej pracy za to samo wynagrodzenie, „Dziennik Finansowy. The Wall Street Journal. Polska” 25 VIII 2008, s. 7.

7 R. Marx, Kapitał. Mowa w obronie człowieka, tł. J. Serafin, Kraków 2009, s. $30-31$. 


\section{Różnice płacowe}

W historii różnice płacowe tworzyły groźne zjawisko podziału społecznego. Zarobki podkreślały zróżnicowanie społeczeństwa. Według źródeł z II wieku w Indiach dochody roczne kształtowały się następująco: następca tronu, królowa matka, pierwsza żona króla, pierwszy minister i inni dworscy dygnitarze wysokiej rangi 48000 panów; marszałek dworu - 24000 panów; książęta i ich matki - 12 000; wróźbita - 1000 ; nauczyciele i szpiedzy - 1000 1500; rzemieślnicy - 120; służący - 60. Przeciętny koszt utrzymania jednej osoby w ciągu roku wynosił około 50 panów. Wydatki robotnika wynosiły pół pana na miesiąc, a koszt dzienny jego utrzymania wynosił 1/64 pana. W starożytnym Rzymie w III wieku ustalono płacę dniówkową: pastuch zarabiał 20 denarów dziennie, robotnik rolny - 25, artysta malarz - 150. Żywność kosztowała wówczas stosunkowo mało, bo np. funt wołowiny 8 denarów; buty - 100-120 denarów, a płaszcz - 100. Kurtka z futra zajęczego miała cenę ok. 6000 denarów ${ }^{8}$.

Wiele wieków później „człowiek radziecki” odczuwał swą pracę jako pozbawioną sensu, gdyż nie gwarantowała mu ona warunków godnego życia. Oblicza się, że dopiero w 1963 roku płaca realna robotnika rosyjskiego osiągnęła poziom z 1913 roku. $\mathrm{Na}$ początku lat 80 . XX wieku przeciętna rodzina radziecka musiała wydawać 54,4 proc. swych dochodów na artykuły żywnościowe, czyli nieco więcej niż przeciętna rodzina rosyjska w 1900 roku. W 1913 roku robotnik rosyjski był w stanie nabyć za swą dniówkę: $54 \mathrm{~kg}$ chleba lub 11,8 kg cukru, 3,4 kg masła lub 8,7 kg mięsa, natomiast w latach 1976-1977: $40 \mathrm{~kg}$ chleba, 7,9 kg cukru, 1,98 kg masła lub $2,85 \mathrm{~kg}$ mięsa. Na 1 litr mleka rosyjski robotnik pracować musiał w 1913 roku 11 minut (w 1976 roku 21 min.), na 1 jajko - 2,3 min. (1976 - 9,7), na 1 kg ziemniaków - 3 min. (1976 - 72), na 1 parę męskich butów - 1000 min. (1976 - 2164 min.). 1 libra

\footnotetext{
${ }^{8}$ K. Dziedzic, Kronika śmierci, Kraków 1995, s. 22, 30.
} 
( $\mathrm{lb}=$ funt $=0,4536 \mathrm{~kg})$ mięsa kosztowała obywatela radzieckiego 94 min. pracy (amerykańskiego tylko 16), 1 lb cukru - 29 min. (USA - 4), tuzin jajek - 116 min. (USA - 12), para pończoch nylonowych - 114 min. (USA - 16), mydło - 72 min. (USA - 5), żarówka 100 watowa $-30 \mathrm{~min}$. (USA $-8 \mathrm{~min}$.) ${ }^{9}$.

Podobnie nieefektywna była praca w rolnictwie. 25 proc. pracującej ludności Związku Radzieckiego było zatrudnione w rolnictwie (w USA - od 2,7 do 3 proc.). Stawka za godzinę pracy w rolnictwie wynosiła 44 kopiejki (59 centów wg oficjalnego kursu radzieckiego), a w USA - 2 dolary 30 centów. Cena tony zboża kupionej w USA była dwa razy niższa niż wyprodukowanej w ZSRR. Związkowi Radzieckiemu taniej było zatem kupować zboże za granicą, niż produkować je u siebie. ZSRR był ostatnim państwem $\mathrm{z}$ dziewiętnastowiecznym proletariatem $\mathrm{z}$ racji „nędznych płac, ale także z powodu wzorcowego obrazu robotnika, upowszechnionego przez plakaty, filmy i powieści. Do tego obrazu chcąc nie chcąc, rzeczywiście istniejący robotnicy musieli się upodobnić" 10 .

Niskie płace są też podstawą odczuwania przez grupy robotników niesprawiedliwości i istotną przyczyną manifestacji i strajków organizowanych przez związki zawodowe. Postulaty płacowe są nadal istotnymi elementami żądań związkowych w Polsce i źródłem podziału ludzi pracy na pracowników o wieloletnich gwarantowanych płacach oraz zatrudnionych w średnich firmach, gdzie czują się poniewierani i gdzie pracodawcy tępią wszelkie przejawy działalności związkowej. Nadal jednak 65 proc. Polaków uważa, że organizacje broniące praw pracowniczych są potrzebne, chociaż członkostwo w „Solidarności” deklaruje 2 proc. dorosłych Polaków (600 tys.), a przynależność do OPZZ 1 proc. Najbardziej radykalny „Sierpień ' 80 ” ma zaledwie kilkadziesiąt tysięcy

\footnotetext{
${ }^{9}$ M. Ciesielczyk, Bilans 70 lat komunizmu w ZSRR, mps, s. 9-11.

10 M. Heller, A. Niekricz, Utopia u władzy, t. 2, Poznań 2016, s. 272-273.
} 
członków. W sumie wszystkich członków związków zawodowych w Polsce jest nie więcej niż 2 mln. („Solidarnośćc” w 1981 roku liczyła ok. 10 mln członków) ${ }^{11}$.

„Kwestia płacowa” pozostaje pojęciem ciągle otwartym, czekającym na doprecyzowanie. Z pewnością jest to ważny element procesu gospodarczego, który wymaga zharmonizowania pracy i kapitału. Podporządkowanie logice rynkowej praw gospodarczych nie wyklucza, ale domaga się przemyślanego podejścia do rynku pracy. Płaca bowiem jest nie tylko kwestią ekonomiczną, ale także społeczną i moralną ${ }^{12}$. Własność prywatna, której istotnym źródłem jest praca, umożliwia budowanie więzi międzyludzkich, tworzy strukturę społeczną. Jezus nie oczekuje od wierzących rezygnacji z posiadanych dóbr (Łk 19, 8n). Sam nie pochodził z najniższych warstw społecznych, lecz (według współczesnych klasyfikacji) z klasy średniej. Podobnie jak św. Józef był cieślą. Przypominał, że dobra materialne nie powinny zdominować życia człowieka (Mt 6, 24; Łk 16, 13), oczekiwał mądrego gospodarowania nimi, by służyły budowaniu więzi z innymi - wzywał, by tak „zyskiwać przyjaciół” (Łk 16, 9). Odpowiednie zarządzanie jest błogosławieństwem (Łk 16, 10-12), ale jednocześnie pozostawał suwerenny wobec dóbr ziemskich ${ }^{13}$. Posiadane przez człowieka dobra materialne i wolność od nieustannej troski o nie sprawia, że staje się on bardziej samodzielny. Niekiedy też owe dobra zamykają go na sprawy innych, na pomaganie innym. Psychologia posiadania potwierdza to niebezpieczeństwo „egoizmu bogatych”, co otwiera przestrzeń dla formacji zmierzającej do chrześcijańskiej miłości, która powinna go pokonać. Innym zagrożeniem

11 A. Besançon, Imperium rosyjskie, w: Sowietskij Sojuz, red. J. Karpiński, I. Lasota, tł. J. Karpiński, New York 1988, s. 15.

12 E. Wesołowska, Bonzowie i pariasi, „Newsweek Polska” (2009) nr 25, s. 1822. Por. Z. Jacukowicz, Płaca godziwa a minimum socjalne w Polsce, „Ethos” (1995) nr 32, s. 142-153; W. Jarmułowicz, Negocjacyjny mechanizm regulacji płac. Konflikt i porozumienie, „Ethos” (1995) nr 32, s. 154-160.

13 A. Dylus, „Kwestia płacowa” dawniej i dziś, „Ethos” (1995) nr 32, s. 99-112. 
jest utrata pieniędzy, co może doprowadzić człowieka do depresji, a nawet samobójstwa ${ }^{14}$.

\section{Katolicka nauka społeczna o płacy}

Katolicka nauka społeczna na różne sposoby podchodziła do kwestii płacy. Najpierw wskazywano na konieczność obopólnej zgody zainteresowanych stron, wolny układ między pracodawcą a pracownikiem co do wysokości zarobku (RN 34). Równowartość świadczeń i produktywności, według zasady ,jaka praca, taka płaca" okazuje się zbyt ciasna. Wysokość płacy należy ustawić w sprawiedliwej relacji do pracy. Bez tej relacji płaca staje się rodzajem jałmużny, zapomogi czy zasiłku. Nie można mówić o miłości społecznej bez elementarnej sprawiedliwości. Ostro krytykowano liberalną koncepcję „spiżowego prawa pracy”, sformułowaną przez Ferdynanda Lassalle’a, zgodnie z którą płaca ma oscylować wokół poziomu gwarantującego minimum egzystencji, by dzięki niej mogła być odtworzona siła robocza (inaczej nastąpi spadek podaży pracy, co spowoduje wzrost jej ceny). Krytyka wskazywała na niesprawiedliwość i dehumanizację pracy. Katoliccy myśliciele wskazywali na potrzebę przezwyciężenia proletaryzmu i określenia warunków godziwego życia pracowników. Płaca powinna być sprawiedliwa, czyli odpowiadać wydajności pracy, ale też i słuszna, czyli zaspokajająca potrzeby pracownika. Płaca sprawiedliwa powinna więc gwarantować nie tylko godziwe warunki życia, ale także umożliwiać poprawę dobrobytu i rozwój kulturowy człowieka (QA 75). Tak więc powinna wystarczyć na możliwe oszczędzanie w celu zgromadzenia skromnego majątku (QA 63) oraz powinna być „płacą rodzinną” - „by ojcowie rodzin taką otrzymywali płacę, która by odpowiednio zaspokoiła przeciętne potrzeby ży-

${ }^{14}$ H. Giesen, Problem posiadania majatku w wypowiedziach Jezusa i w tradycji nowotestamentalnej, „Communio” 109 (1999) nr 1, s. 42-56. 
cia rodzinnego” (QA 71) ${ }^{15}$. Słuszne wynagrodzenie powinno też uwzględnić „,stan przedsiębiorstwa” oraz „dobro wspólne” (QA 7275). Przekroczenie funduszu płac byłoby bowiem klęską samych robotników (QA 72). Encyklika Jana XXIII Mater et Magistra (1961) postulat słusznego wynagrodzenia uzupełnia o „wymagania dobra wspólnego wszystkich narodów" (MM 71), w tym także przyszłych pokoleń. Dobrobyt, o który zabiegamy, powinien bowiem też uwzględniać przyszłość (MM 79). Kryteria sprawiedliwej płacy muszą też uwzględniać racje dobra społecznego: „tak zbyt niskie, jak i zbyt wysokie zarobki stają się przyczyną bezrobocia” (QA 74). Do innych elementów ekonomii, do których należy odnosić płace, należą np.: inflacja, płace realne, zjawisko tzw. kominów płacowych czy nożyc cen. Dlatego też pojawia się w nauce społecznej Kościoła postulat dostosowania płac do cen towarów (indeksacja płac), likwidacja lub ograniczenie rażących dysproporcji płacowych między grupami społecznymi i wśród samych pracowników, występujących nawet w skali międzynarodowej (QA 75; MM 79-80).

Odpowiedzialni za kształtowanie płac są przede wszystkim pracodawcy (RN 17), ale także państwo i sami pracownicy (QA 73). Pracownicy jako „mniej zdolni do samoobrony” (RN 17) byli adresatami postulatów ochrony i opieki. Zdawano sobie jednak sprawę z tego, że „kwestia płacowa” związana jest z ogólną „naprawą obyczajów”, której musi towarzyszyć „reforma urządzeń” i „odnowienie ustroju społecznego" (QA 77).

Postulat „płacy rodzinnej” został uzupełniony przez Jana Pawła II alternatywną propozycją, by rodzinne wyrównanie dochodów mogło następować za pośrednictwem różnych świadczeń społecznych: zasiłku rodzinnego, dodatków macierzyńskich itp., czyli środków nieobciążających wyłącznie rodzimej firmy pracownika (LE 19). Taka propozycja uwalniała przedsiębiorcę zatrudniającego pracowników obarczonych rodzinami od obciążeń, które mog-

15 M. Buchanan, Kasa mąci w głowie („New Scientist”, 18 III 2009), „Forum” (2009) nr 21, s. 26-29. 
ły obniżać konkurencyjność jego firmy. Jan Paweł II zwrócił uwagę, że „sprawa sprawiedliwej zapłaty za wykonywana pracę" jest „kluczowym problemem etyki społecznej”, a nadto „sprawdzianem sprawiedliwości całego ustroju" (LE 19). Nie zmienia tego fakt, że współcześnie nastąpił ogromny rozwój form własności, struktur formalnoprawnych podmiotów gospodarczych (akcjonariat, spółki pracownicze, różne formy współwłasności) ${ }^{16}$.

Godziwe wynagrodzenie jest elementem ładu gospodarczego i społecznego. Dlatego też znalazło szerokie odbicie w wielu międzynarodowych umowach, m.in. w Powszechnej Deklaracji Praw Człowieka (1948) zagwarantowano prawo do wynagrodzenia zapewniającego „wszystkim pracownikom przynajmniej przyzwoite utrzymanie dla nich samych i ich rodzin" - art. 7, ust. 2a. Podobnie stwierdza Europejska Karta Socjalna (1961): „wszyscy pracownicy mają prawo do godziwego wynagrodzenia, wystarczającego do zapewnienia im, jak i ich rodzinom, właściwego poziomu życia” (ust. 4, cz. I). Międzynarodowa Organizacja Pracy już w 1928 roku przyjęła Konwencję nr 26 w sprawie mechanizmu ustalania płacy minimalnej, a rok później Konwencję nr 30, które określiły pewne zasady: wdrożenie płacy minimalnej ma nastąpić po konsultacji przedstawicieli pracowników i pracodawców ze specjalistami; w procesie regulacji mają mieć równy udział pracodawcy, jak i pracownicy; wyłącznie władza państwowa jest kompetentna dla zatwierdzenie decyzji o obniżeniu płac minimalnych; należy propagować stawki minimalne wśród pracowników i pracodawców oraz kontrolować ich przestrzeganie, a karać ich lekceważenie; zapewnić pracownikom w drodze sądowej dochodzenie do rekompensaty za bezprawne obniżenie płacy ${ }^{17}$.

16 A. Dylus, „Kwestia płacowa” dawniej i dziś, dz. cyt., s. 99-112; L. Dyczewski, Płaca sprawiedliwa i stuszna, „Ethos” (1995) nr 32, s. 113-121; J. Wratny, Koncepcja płacy sprawiedliwej a niektóre aktualne problemy prawa pracy i polityki płac w Polsce, „Ethos” (1995) nr 32, s. 133-141.

17 Cyt. za: J. Kropiwnicki, Płaca minimalna $w$ Polsce a standardy międzynarodowe, „Ethos” (1995) nr 32, s. 122-132. 
Form radykalnej niesprawiedliwości płacowej może być wiele. Do najbardziej widocznego ataku na pensję dochodzi wówczas, gdy pracodawca wstrzymuje jej wypłatę, zalega z nią, opóźnia przekazanie wynagrodzenia. Chociaż prawo pracy przewiduje kary dla pracodawcy zalegającego $\mathrm{z}$ wypłatą pensji, to jednak wciąż dochodzi do takich sytuacji. Przykładowo w Polsce, po przeprowadzeniu w 2009 roku badania w 40 tys. zakładów pracy, Państwowa Inspekcja Pracy stwierdziła, że w II półroczu 2008 roku 23 tys. osób nie otrzymało pensji (niewypłacone należności wynosiły $44 \mathrm{mln}$ zł), a w I półroczu 2009 roku płacy nie otrzymało 46 tys. osób (kwota zaległych pensji przekroczyła $68 \mathrm{mln}$ zł) ${ }^{18}$.

Inna formą niesprawiedliwości wobec pracowników jest niestworzenie im właściwych, godziwych warunków pracy. Brak czasu na posiłek, przynaglanie do pracy ponad siły, niezapowiadane przedłużanie czasu pracy, niepłacenie dodatków za godziny nadliczbowe itp. Na pytanie o zaniżanie płac jeden z polskich kierowników supermarketów odpowiedział: „Dlaczego tak słabo płacimy? Skoro są tysiące chętnych, którzy godziliby się pracować nawet za mniej, to dlaczego mamy płacić więcej, niż pozwala rynek? [...] Mniej już się nie da, ze względu na przepisy. My jesteśmy za poważną firmą, żeby ryzykować utarczki z urzędami ${ }^{19}$. Wykorzystywanie dramatycznej sytuacji ekonomicznej dla dowolnego kształtowania płac, bez uwzględnienia najprostszej sprawiedliwości, jest częstym źródłem poniżenia pracownika. W Londynie 90 proc. wszystkich słabo opłacanych prac wykonują imigranci, najczęściej zatrudniani nielegalnie. Ich sytuacja ekonomiczna jest i tak lepsza niż w kraju ojczystym, więc nie dopominają się o sprawiedliwość. Ich milczenie jest cynicznie wykorzystywane przez pracodawców. Biały, odpowiednio wykształcony i wykwalifikowany pracownik jest najczęściej poszukiwanym „towarem” w krajach

18 Iggy, Pracodawcy czują kryzys, „Przekrój” (2009) nr 27, s. 15.

19 T. Tosza, Pięć godzin i trzy kwadranse, „Gazeta Wyborcza” (2000) nr 211, s. 12-13. Por. M. Wlekły, Niewolnicy z wyboru, „Newsweek Polska” (2008) nr 39, s. 60-61. 
Unii Europejskiej. Do wyludniających się miast i na tereny przemysłowe przybywają imigranci - np. Irlandia ma dzięki napływowi imigrantów najwyższą od 150 lat liczbę mieszkańców (ponad 50 proc. to Polacy). Dzięki ich pracy PKB Irlandii rośnie rocznie o 2,5 proc. ${ }^{20}$. W Chinach dla przybywających ze wsi pracowników przetrwanie w mieście jest dużym wyzwaniem. Pracownicy migracyjni nie otrzymują bowiem wynagrodzenia za nadgodziny. Chociaż kodeks pracy gwarantuje 8-godzinny dzień pracy, 44 godziny pracy w tygodniu, to na budowie pracują oni przeciętnie 10 godzin dziennie przez $27 \mathrm{dni}$ w miesiącu. Otrzymywanie zarobków z opóźnieniem lub zupełny brak wynagrodzenia to najczęstszy problem wieśniaka, podejmującego pracę w miejskim środowisku. Płaca jest zaniżona: przeciętne wynagrodzenie robotnika na budowie w dużym mieście wynosi od 40 do 60 yuanów (13-19,5 zł) dziennie, z czego ok. 10 yuanów (3,2 zł) odliczane jest na poczet wyżywienia. Przeciętnie pracownik migracyjny zarabia miesięcznie 1200 yuanów (ok. 382 zł), gdy przeciętny zarobek mieszkańca miasta to 5 tys. yuanów (ok. 1590 zł). Chiński kodeks pracy przewiduje wypłacanie miesięczne pensji, płaca „nie może być zredukowana lub wypłacana z opóźnieniem bez odpowiedniego uzasadnienia” (art. 50). Jednak imigranci nie posiadają umowy o pracę albo też nie posiadają ich kopii, więc są bezsilni wobec pracodawcy ${ }^{21}$.

Udręką pracowników staje się także inna forma ich wykorzystywania - tzw. mobbing, czyli trwające dłuższy czas psychiczne nękanie pracowników, celowe i konsekwentne. Ofiary tego zjawiska są przez osoby mobbujące (tzw. mobberów) systematycznie izolowane, nękane, prześladowane, upokarzane i szykanowane. Niekiedy łączy się to z niskim uposażeniem. Celem jest bowiem

${ }^{20}$ M. Rybarczyk, Niewidzialni, „Newsweek Polska” (2009) nr 14, s. 42-43; J. Piński, M. Zdziechowska, Europejska lista plac, „Wprost” (2006) nr 39, s. $42-48$.

${ }^{21}$ H. Shen, Obywatele drugiej kategorii, „Niezależna Gazeta Polska” z dnia 4 IV 2008, s. 14-15. 
kompletne zastraszenie obiektu ataku, który ma być umyślnie i świadomie wyizolowany lub zniszczony. Badacze wyróżnili ponad sto różnych wariantów mobbingu, w tym ataki skierowane na: wyniki pracy (niesłuszne oskarżenia o uszkodzenia, kradzieże); pozycję w firmie (oszczerstwa, zniesławianie, insynuacje, manipulowanie wykazami przepracowanych godzin); poczucie własnej wartości (obrażanie, szkalowanie, upokarzanie, niepokojenie, dokuczanie, poniżanie, ośmieszanie, złośliwości, deprecjonowanie, obwinianie o złe zamiary, głupotę czy nielojalne postępowanie); sferę prywatną (oczernianie, dyskredytowanie w obecności członków rodziny lub przyjaciól, nocny terror telefoniczny, stała krytyka prywatnych zainteresowań lub przekonań religijnych); zdrowie i nietykalność cielesną (fizyczne ingerencje, stosowanie siły - także „niechcący”, molestowanie seksualne, świadome zlecanie zadań szkodliwych dla zdrowia, wykorzystywanie czyichś lęków, urazów lub chorób, aż po sugerowanie samobójstwa). Bezbronność pracownika znajdującego się w sytuacji przymusowej ułatwia tego typu dręczenie ${ }^{22}$.

Także społeczności międzynarodowe mogą celowo wykorzystywać słabszych. Przykładem ekonomicznego wykorzystywania zniewolonych narodów była gospodarka III Rzeszy. Według obliczeń w latach 1939-1945 Rzesza uzyskała z grabieży w krajach europejskich minimum 2 biliony euro. Na samych robotach przymusowych zarobiła 130 mld euro. Doskonałość ich zbrodni polegała także na uniemożliwieniu odzyskania ich łupu. Znaczna część tej sumy posłużyła do sfinansowania działań militarnych, a reszta była redystrybuowana do odbiorcy indywidualnego - niemieckiego obywatela - w postaci zwolnień podatkowych, świadczeń socjalnych, podwyżek, wczasów pracowniczych, sztucznie utrzymywanych cen towarów. Po wojnie niemożliwe okazało się restytuowanie zagrabionych dóbr. Zasada obowiązku reparacyjnego dla

22 A. Huber, Praca z udręką („Psychologie Heute” 2008), „Forum” (2008) nr 41, s. 28-30; G. Manzone, Mobbing i bossing a nowa kultura przedsiębiorczości, „Społeczeństwo” (2005) nr 3, s. 485-498. 
Niemiec została ustalona w Jałcie i Poczdamie. Odszkodowania określono na poziomie 20 mld dolarów. Lecz alianci pobierali reparacje tylko przez dwa lata, w 1950 roku Moskwa obniżyła o połowę wysokość reparacji z obszaru NRD, a trzy lata później je wstrzymała całkowicie. W 1952 roku w tzw. umowie londyńskiej Niemcy uzyskały całkowite zawieszenie spłaty swoich zobowiązań finansowych wynikających nie tylko z II wojny światowej, ale jeszcze z zaciągniętych długów z I wojny światowej. Po zjednoczeniu Niemiec (1990) rząd niemiecki powołał w 2000 roku Fundację „Pamięć, Odpowiedzialność i Przyszłość”, której majątek został przeznaczony na wypłaty dla żyjących byłych robotników przymusowych. Wypłacono 5 mld euro, co stanowi jedynie 3,7 proc. dochodu z tych robót. Reszta, czyli 125 mld euro, wzmocniło niemiecką gospodarkę ${ }^{23}$. Niemieckie państwo rzeczywiście przegrało wojnę, ale nie gospodarka. Podobna sytuacja dotyczy wielu gospodarek zbudowanych na łupach $\mathrm{z}$ wielowiekowej kolonizacji świata. Ta międzynarodowa grabież ciągle nie została rozliczona.

\section{Wyzysk}

W historii ekonomii już od dawna dyskutowano nad wyzyskiem jako formą ekonomicznej niesprawiedliwości, która boleśnie rani pracujących. W dyskusji tej ważnym głosem była nauka Karola Marksa o alienacji jako formie wyzysku robotników. Alienacja jest pojęciem związanym bezpośrednio z jednym z głównych problemów analizy marksistowskiej, z wyzyskiem. Był on definiowany przez Marksa dwukrotnie, i to odmiennie.

1. „Młody Marks” w nieukończonej rozprawie pt. Rękopisy ekonomiczno-filozoficzne" z 1844 roku, ogłoszonej dopiero w 1932 roku (w Polsce w 1958 roku), mówił o pracy wyzyskiwanej, wyalie-

${ }^{23}$ M. Muszyński, Komu Niemcy ukradli dobrobyt, „Wprost” (2007) nr 35, s. $22-25$. 
nowanej, jako o tej, która pozostaje w sprzeczności z istotą, naturą człowieka. Tym samym Karol Marks zakładał określoną antropologię. Założenie to pozostaje w sprzeczności z zasadniczą tezą marksizmu, że wszystko, również natura człowieka, jest tworzywem dla pracy. W tekście „szóstej tezy o Feuerbachu” (z Tez o Feuerbachu z 1845 roku) czytamy, że „istota człowieka to nie abstrakcja tkwiąca w poszczególnej jednostce”, bo jest ona „w swojej rzeczywistości całokształtem stosunków społecznych".

Marks obejmował wszystkie formy wyzysku pojęciem „alienacji”, „wyobcowania”. Wyobcowanie to dla niego każda sytuacja, w której człowiek znajduje się „poza swą istotą”, staje się „obcy samemu sobie", w której to, taki jaki jest, przeciwstawia się temu, kim jest. Wymienia kilka form wyobcowania: a) alienacja przez produkt - „robotnik staje się towarem tym tańszym, im więcej towarów wytwarza"; b) alienacja przez sam rodzaj wykonywanej pracy - „praca jest dla robotnika czymś zewnętrznym, tzn. nie należy do jego istoty, wobec tego robotnik nie potwierdza się w swojej pracy, lecz zaprzecza, nie czuje się zadowolony, lecz nieszczęśliwy, nie rozwija swobodnie energii fizycznej i duchowej, lecz umartwia swe ciało i rujnuje się duchowo"; c) wyobcowanie z gatunku ludzkiego - „dochodzi do tego, że człowiek odczuwa jako nieprzymuszone tylko swoje funkcje zwierzęce, jedzenie, picie i płodzenie, co najwyżej jeszcze mieszkanie, ubieranie się itp., i w swych funkcjach ludzkich czuje się tylko zwierzęciem. To, co zwierzęce, staje się ludzkie, a to, co ludzkie - zwierzęce"24.

2. „Dojrzały Marks” odwoływał się do podstawowych praw ekonomii politycznej. Według Encyklopedii filozoficznej (Lipsk 1975) wyzysk jest wynikiem faktu, że właściciel środków produkcji przywłaszcza sobie cudzą pracę (wartość dodatkową, a czasami i część wartości właściwej). Wyzysk powstaje wtedy, gdy rozwój społecznych sił wytwórczych umożliwia uzyskanie wartości

24 J. Tischner, Filozofia chrześcijańska w dialogu z marksizmem, Kraków 1979, s. 18-23. 
dodatkowej, która następnie może być przywłaszczona przez posiadacza środków produkcji. Aby znieść wyzysk, należy tak zorganizować życie społeczne, by wartość dodatkowa wracała do robotnika $^{25}$.

Dwie koncepcje wyzysku doprowadziły do licznych sporów w gronie marksistów. Stalin pisał: „W ustroju socjalistycznym (...) nie ma już wyzyskiwaczy ani wyzyskiwanych. Wytworzone produkty dzieli się według pracy zgodnie z zasadą: «kto nie pracuje, ten nie je»"26.

Uznany za jednego z rewizjonistów, Adam Schaff pisał:

Alienacja występuje więc i w społeczeństwie socjalistycznym. I taka, która jest zwyczajnym, nieprzezwyciężonym jeszcze reliktem przeszłości; i taka również, która bardziej organicznie, trwalej wiąże się z warunkami nowego ustroju. W każdym razie zagadnienie to istnieje i musi być przedmiotem refleksji i realnej troski ${ }^{27}$.

Rozwój myśli ekonomicznej wykazał niesłuszność założeń Marksa odnośnie do wyzysku, pracy, płacy i relacji zachodzących między nimi. Amerykański ekonomista Francis Walker udowodnił, że płace i zyski wzrastają razem w miarę, jak zwiększa się efektywność prowadząca do wzrostu zysków i płac. Niedługo później William Jevons i Carl Menger zastąpili teorię wartości opartą na pracy tzw. subiektywną teorią wartości. Wartość produktu, według nich, jest określona przez popyt krańcowy, tzn. produkt wart jest tyle, ile ktoś gotowy jest za niego zapłacić. Konsument więc, a nie producent przesądza o wartości produktu ${ }^{28}$. Wobec istniejącego w ekonomii wyzysku mającego różne postaci pojawiła się idea odpowiedzialnego inwestowania, zwana SRI (ang. socially responsible

${ }^{25}$ J. Tischner, Filozofia chrześcijańska..., dz. cyt., s. 20-21.

${ }^{26}$ J. Stalin, Zagadnienia leninizmu, Warszawa 1949, s. 513.

27 A. Schaff, Marksizm a jednostka ludzka, Warszawa 1965, s. 81.

${ }^{28}$ C. B. Crocker, O zysku słów kilka, „Stańczyk“ (1988) nr 9, s. 47. 
investing). Obecnie jest ona realizowana w Stanach Zjednoczonych, a jej łączna wartość dochodzi do 2,7 bln dol. SRI polega na inwestowaniu, czyli pomnażaniu pieniędzy, w sposób etyczny i zrównoważony. Za twórców tej idei uważa się przywódców protestanckich ruchów religijnych w USA i Wielkiej Brytanii. Już bowiem w połowie XVIII wieku kwakrzy zabraniali swoim wyznawcom udziału w przedsięwzięciach powiązanych z niewolnictwem. W latach 1970-1990, w początkach współczesnego SRI, domagano się od funduszy emerytalnych informacji, czy pieniądze są inwestowane w firmy czerpiące zyski z wojny w Wietnamie. Dzisiaj odchodzi się od maksymalizacji zysku za wszelką cenę, przy przestrzeganiu zasad odpowiedzialności społecznej i realizowaniu ważnych społecznie celów. Od firm wymaga się: przejrzystości; dbania o prawa pracownicze; niewspierania inwestycji moralnie wątpliwych (firm - udziałowców produkcji min przeciwpiechotnych); ochrony środowiska naturalnego; odrzucania obligacji państw, które nie przestrzegają praw człowieka; omijanie spółek, którym zarzuca się zmowy kartelowe, korupcje, dyskryminacje dostawców, czy działających w branżach: alkoholowej, zbrojeniowej, tytoniowej, pornograficznej, energii atomowej, czy produkcji środków antykoncepcyjnych. Pojawiło się także nowe pojęcie, tzw. grzeszne inwestowanie (sinful investing lub vice investing), będące jako działanie nie do zaakceptowania przez SRI ${ }^{29}$.

Ekonomia może być rozumiana na różne sposoby. W podręcznikach ekonomii jest definiowana jako nauka o organizowaniu się społeczeństwa dla rozwiązywania problemu niedoboru. W praktyce jednak od dłuższego czasu trwała koncepcja ekonomii rozumianej jako nauka o maksymalizacji zysków. Takie jej rozumienie nie pozwala formułować celów ekonomii, bo jak słusznie zauważył amerykański ekonomista Herman Daly, konsultant Fundacji Forda oraz Banku Światowego:

29 P. Stasiak, Zysk bez wyzysku, „Sztuka Życia. Polityka” (2008) nr 37, dodatek, s. 28-33. 
Jeśli istnieje dobrze zdefiniowany cel, wzrost jest wtedy limitowany jego osiągnięciem. Jeśli na przykład wzrost gospodarczy miałby służyć zaspokojeniu potrzeb ludzi biednych, to powinien ograniczać się do wytwarzania rzeczy tym ludziom potrzebnych i zatrzymać się, gdy biedni przestaliby być biednymi. Ale jeśli wzrost ma się nigdy nie zatrzymać, a do tego właśnie sprowadza się ekonomia wzrostu, nie wolno nam definiować precyzyjnie naszych celów, gdyż jeśli je osiągniemy, dalszy wzrost straci sens ${ }^{30}$.

Wzrost jest stymulowany chciwością. Rynek ustala, co jest właściwe, a co nie, co dobre, a co złe. Wzrost ekonomiczny i konkurencja stają się jedynym kryterium sensownej egzystencji człowieka. Efektem „wzrostomanii” jest stworzenie z ekonomii celu samego w sobie, czyli masowej produkcji niezaspokojenia, ciągle nowych potrzeb, które są niezbędne dla dalszego rozwoju - jak to określił brytyjski socjolog Jeremy Seabrook ${ }^{31}$. Izraelski pisarz Amos Oz zauważył:

Wszystko kończy się tym, że większość moich znajomych pracuje ciężej, niż powinni po to, żeby zarobić więcej pieniędzy, niż im naprawdę potrzeba, żeby kupić nowe rzeczy, których naprawdę nie potrzebują, żeby zaimponować ludziom, których tak naprawdę nie lubią ${ }^{32}$.

Przy tak rozumianej ekonomii nie zauważa się, gdyż jest to niezgodne z pierwotnym zamysłem, że istnieje problem biedy, a także ludzi potrzebujących, których praca nie wystarcza do udziału w gospodarczym wyścigu - są raczej jej ofiarami. Podczas konferencji

${ }^{30}$ H. Daly, The Steady-State Economy: Alternative to Growth Mania, w: Economic alternatives for Eastern Europe, London 1993, s. 18.

31 Por. A. Paszewski, Dylemat Europy: czy udział w wyścigu ekonomicznym czyni ja przyjazna człowiekowi?, „Znak” (2008) nr 642, s. 84.

32 A. Oz, „Gazeta Wyborcza”, 1-2 VII 2000. 
Unii Europejskiej w Goeteborgu w 2001 roku zwrócono uwagę, że dochody Europejczyka są dziś pięć razy większe niż na początku $\mathrm{XX}$ wieku, ale wciąż jedna osoba na sześć cierpi biedę. W Polsce dotyczy to 4-6 mln ludzi. Bulwersujący jest fakt, że nie dojada 800 tys. polskich dzieci, mimo że w kraju nie brakuje żywności ${ }^{33}$.

Przeraża obojętność tych, którzy mają wpływ decyzyjny na gospodarkę. Już John Stuart Mill (1806-1873), filozof i ekonomista, narzekał: „na próżno spoglądamy na klasy pracujące w poszukiwaniu uczciwych i dumnych, którzy postanowią pracować w zamian za dobra płacę; w większości starają się oni uzyskać jak najwięcej, dając przy tym - na ile to możliwe - jak najmniej”34. Bezduszna ekonomia wzrostu generuje całe grupy biedoty, w tym bezrobotnych. Robotnik pozbawiony pracy to zwykle pierwsza ofiara kryzysu, krachu czy słabej kondycji gospodarki danego regionu. Podczas kryzysu gospodarczego lat 30. XX wieku bezrobocie dotknęło miliony ludzi. Na przełomie 1932 i 1933 roku bezrobotnych było $15 \mathrm{mln}$ Amerykanów w wieku produkcyjnym, czyli bezrobocie sięgnęło 25 proc.. Amerykańscy bezrobotni nie otrzymali żadnego państwowego, choćby tylko przejściowego, wsparcia. Inna była sytuacja w Europie, gdyż bezrobotni mogli liczyć, np. w Niemczech, na chwilowe wsparcie. W Niemczech ubezpieczenie bezrobotnych zostało wprowadzone w 1927 roku, gdy ministrem pracy był ksiądz katolicki Heinrich Brauns ${ }^{35}$. Zdobywanie zysku nie może przesłonić praw człowieka. Upominał się o to papież Jan Paweł II, gdy w przemówieniu w Sosnowcu stwierdził:

w imię praw rynku zapomina się o prawach człowieka. Jest tak na przykład, gdy rachunek ekonomiczny usprawiedliwia pozbawienie pracy kogoś, kto wraz z nią traci wszelkie per-

33 Por. A. Paszewski, Dylemat Europy..., dz. cyt., s. 83.

34 J. S. Mill, Principles of Political Economy, London 1867, t. 2, s. 337.

35 R. Marx, Kapitał. Mowa w obronie człowieka, s. 186. Por. Jan Paweł II, Świat pracy potrzebuje ludzi prawego sumienia. Przemówienie podczas Liturgii Słowa, Sosnowiec, 14 VI 1999, nr 2. 
spektywy na utrzymanie siebie i rodziny. Dzieje się tak również, gdy dla zwiększenia produkcji odmawia się pracownikowi prawa do odpoczynku, do troski o rodzinę, do wolności w podejmowaniu decyzji o kształcie własnej codzienności. Jest tak zawsze, gdy wartość pracy jest określana nie poprzez wysiłek człowieka, ale poprzez cenę produktu - co powoduje, że wynagrodzenie nie odpowiada trudowi ${ }^{36}$.

\section{Solidaryzm jako propozycja}

Etyka pracy może i powinna doprowadzić do spotkania pracowników i pracodawców, powinna budować jedność między nimi. Wszak każde przedsiębiorstwo, nawet mała prywatna firma, to konkretne publiczne zobowiązanie i podjęcie troski o choćby kilku pracowników. Bezmyślna pogoń za pieniądzem niszczy wspólnotę, ale dobre gospodarowanie obdarowuje innych nadzieją i stwarza pokój między ludźmi.

Odpowiedzią na zagrożenie grzechem niesprawiedliwości społecznej i ekonomicznego wyzysku słabszych jest postulat budowania społeczeństwa solidarnego, w którym silniejsi i bogatsi biorą odpowiedzialność za słabszych i biednych, świadomi więzi, jakie łączą całą rodzinę ludzką. Nie wystarczy postulat tolerancji, który jest zaledwie postulatem wystarczającym do zaistnienia sprawiedliwości, lecz jej nie powoduje, a tym bardziej nie zapewnia. Dopiero w solidarności następuje uznanie cierpień i niedoli innych ludzi za sprawę własnej odpowiedzialności, a ich złagodzenie, czy nawet usunięcie, za własne zadanie. Tolerancja może przybierać kształt znieczulenia i obojętności ${ }^{37}$.

${ }^{36}$ Z. Bauman, Ponowoczesność jako źródło cierpień, Warszawa 2000, s. 100nn.

37 M. Ossowska, Normy moralne, Warszawa 1985, s. 212. Por. P. Łukasiewicz, Wartości zbiorowe a wartości publiczne, w: Wartości i ich przemiany, red. A. Pawełczyńska, Warszawa 1992, s. 171-186. 
Wyrazem głębokiego przekonania o konieczności uspołecznienia jednostki celem udoskonalenia życia zbiorowego jest nauka chrześcijańska, której podstawą jest wezwanie do budowania jedności ze wszystkimi na bazie przykazania miłości. Praktycznym przełożeniem tej nauki była Reguła św. Benedykta, który w 529 roku położył podwaliny kultury europejskiej. Sformułował on i uświadomił wszystkim proste zasady budowania społeczeństwa: posłuszeństwo przełożonemu (do tej pory mnisi żyli samotnie lub w luźnych strukturach), praca i modlitwa. Odkrył, że filarem ludzkiej aktywności jest dobrze zorganizowana, sensowna i przynosząca efekty praca. Reguła jest jednym z prawzorów kodeksu pracy: wprowadza podział dnia (8-godzinny czas pracy, reszta czasu przeznaczona na modlitwę, odpoczynek - zarabianie nie jest jedynym celem życia), odpowiedzialność pracującego za narzędzia pracy (współudział wszystkich w końcowych kosztach produkcji i procesie gospodarczym), konieczność ciągłej edukacji (jest warunkiem ciągłego udoskonalania procesu pracy, przedsiębiorczości). Efektem wcielenia Reguły w życie było m.in. powstanie kongregacji klasztorów w oparciu o opactwo w Cluny, któremu podlegało 1200 klasztorów (ok. 20000 mnichów). Przełożeni tych klasztorów byli zastępcami opata Cluny i spotykali się z nim raz w roku, by omówić m.in. sprawy finansowe i złożyć raporty. Obecnie przywołuje się często przykłady innych klasztorów, powracających do ideałów św. Benedykta: kilkuosobowa wspólnota $\mathrm{z}$ opactwa Spring w Wisconsin (USA) zarabia ponad pół miliona dolarów rocznie, sprzedając tonery i naboje do drukarek, co zapewnia im całkowitą samodzielność finansową (wystarczy też na pomoc dla biednych), nie czyniąc z nich jednak „drapieżnych kapitalistów"38.

Nauka chrześcijańska może i powinna być traktowana na gruncie ekonomii jako postulat praktykowania ekonomicznej

38 T. Krzyżak, Święty od zarządzania i marketingu, „Ozon” (2006) nr 28, s. 3839; A. Grün, Benedyktyńska praca, tamże, s. 40-41. 
sprawiedliwości społecznej. Wprowadza ona nową perspektywę w postrzeganiu powinności chrześcijan wobec sprawiedliwości już nie tylko z punktu widzenia etyki orientowanej wyłącznie przez ludzki rozum, ale odczytywanej głównie w świetle Objawienia. „Sprawiedliwość ewangeliczna” nie jest jedynie czystym legalizmem, gdyż odnosi się głównie do doświadczeń wewnętrznych, do miłości (por. Mt 5, 21-24). Pragnienie sprawiedliwości jest silnie obecne w Ewangelii (por. Mt 5, 6), a pozostaje wielką ideą także w naszych czasach ${ }^{39}$. Wiele bowiem zjawisk wskazuje, że ciągle w relacjach ekonomicznych między ludźmi pracy i przedsiębiorczości brakuje ofiarności, współdziałania, co nie rokuje dobrze dla ostatecznych efektów ich wysiłku na polu gospodarki ${ }^{40}$.

Podstawą wszelkich relacji społecznych jest zaufanie, które umożliwia współpracę, otwarcie się na innych, współdziałanie w dobru. Zaufanie wielu badaczy traktuje jako poważny element tzw. kapitału społecznego (Samuel Huntington), lecz z tym wiąże się też prawda istnienia poważnych kosztów społecznej nieufności. Pojawiają się one wówczas, gdy kryzys przeżywają instytucje będące głównymi nosicielami wartości - gdy rozbita jest rodzina, ośmieszona religia, kultura ulega degeneracji, a ekonomia ukazuje swe egoistyczne oblicze. Według obliczeń Gary Beckera, laureata ekonomicznej Nagrody Nobla w 1992 roku, aż 80 proc. zasobów w zamożnych krajach stanowi kapitał ludzki, a zaledwie 20 proc. to bogactwa naturalne, zasoby materialne i urządzenia. Współczesny kryzys gospodarczy nie wynikał z niedostatku surowców czy bazy materiałowej, ale był wynikiem zniszczenia zaufania publicznego, zwłaszcza w sektorze bankowym, a więc dotyczył poważnej części kapitału społecznego. Francis Fukuyama w pracy Zaufanie. Kapitał

39 F. F. Madero, Koncpecja sprawiedliwości w nauczaniu Jana Pawła II, „Ethos” (1995) nr 32, s. 181-191. Por. R. G. Malloy, Wiara daje wolność, tł. P. Kaźmierczak, Kraków 2009, s. 171-202.

${ }^{40}$ Por. M. Ossowska, Z etyki stosunków merkantylnych, w: O człowieku, moralności i nauce. Miscellanea, oprac. M. Offierska, M. Smola, Warszawa 1983, s. $351-354$. 
społeczny a droga do dobrobytu napisał, że pomyślność gospodarcza państwa może być zbudowana tylko na zaufaniu społecznym (wzajemnym zaufaniu). Zależy ono np. od stopnia korupcji, która wpływa na koszty transakcji i kontroli. W społeczeństwach o dużym potencjale społecznego zaufania panuje zasada uogólnionej wzajemności, która polega na ofiarowaniu komuś czegoś w poczuciu, że w nieokreślonej bliskości czasowej otrzyma się coś w zamian. George Gilder twierdzi, że źródłem wolnego rynku jest akt dawania: „daj, a będzie ci dane”. Źródłem kapitału społecznego jest świat wartości duchowych i moralnych, który wiąże się z istnieniem rodziny, religii i kultury. To w rodzinie kształtują się takie wartości, jak: rzetelność, uczciwość, solidarność, zdolność do współpracy i poświęcenia, pracowitość, zamiłowanie do ładu i porządku. Religia zaś daje podstawy systemu etycznego - Dekalog chroni ludzką godność, prawo do życia, własność prywatną, walczy z uleganiem wadom i ułomnościom. Kultura niesie z sobą takie wartości, jak empatia, altruizm, poczucie więzi z innymi ludźmi. Gospodarka nie funkcjonuje w abstrakcyjnej pustce, lecz w przestrzeni społecznej, która często warunkuje sposób jej rozwoju ${ }^{41}$.

Nie bez znaczenia jest też poprawa życia społecznego poprzez pojednanie między ludźmi, nawrócenie i pokutę. Świat współczesny pogrążył się w kryzysie polegającym na utracie zaufania publicznego, dlatego tym bardziej potrzebuje znaków i czynów pojednawczych, zdolnych budować nową, poprawioną relację $\mathrm{z}$ innymi ${ }^{42}$. Dopiero wówczas możliwe jest ofiarowanie pomocy, obdarowanie innych, rozbudzenie odpowiedzialności silnych i bogatszych za biedniejszych i słabszych. Pierwsza fundacja dobroczynna na ziemiach polskich powstała w 1073 roku, ufundowana

${ }^{41}$ G. Górny, T. Grzesik, O kryzysie, czyli co podmyło kapitał społeczny, „Fronda” (2009) nr 52, s. 60-65. Por. C. Kowanda, Podatek światowy, „Polityka” (2010) nr 31, s. 40-41.

42 J. Kowalski, Świat współczesny potrzebuje pokuty i nawrócenia, „Sympozjum” (Sakrament spowiedzi świętej dzisiaj) 17 (2008) nr 1, s. 33-56; J. Kowalski, Samo pojednanie u Ojców Kościoła Wschodniego, „Sympozjum” 17 (2008) nr 1, s. 83-94. 
przez księcia Władysława Hermana w podzięce za męskiego potomka. Dzisiaj według Instytutu Polityki Społecznej Uniwersytetu Warszawskiego działa w Polsce ok. 67 tysięcy organizacji dobroczynnych: fundacji, stowarzyszeń, wspólnot, grup. Około 60 proc. ich finansów pochodzi z tzw. środków własnych - od fundatorów, ze sprzedaży produktów, wynajmu, odsetek. 25 proc. pieniędzy otrzymują one ze środków publicznych, a 16 proc. to darowizny indywidualne i od przedsiębiorstw. W 2007 roku ok. 31 proc. Polaków, czyli ok. 9,5 mln dorosłych Polaków przekazało pieniądze lub dary rzeczowe na rzecz organizacji pożytku publicznego. Z możliwości przekazania dowolnej organizacji pożytku publicznego 1 proc. należnego państwu podatku dochodowego PIT w 2003 roku skorzystało 80 tys. podatników (łącznie przekazali ok. 10 mln zł), a w 2007 r. już 1,6 mln osób (kwotę 105 mln zł). Szacunkowa indywidualna dobroczynność osiągnęła wartość do $1 \mathrm{mld}$ zł rocznie (przy dochodach Polaków sięgających $400 \mathrm{mld}$ zł). Cały ten dobroczynny ruch wskazuje na wzrastające zaufanie społeczne Polaków, coraz bardziej odpowiedzialne dostrzeganie potrzeb innych i chęć niesienia pomocy (ok. 20 proc. darczyńców wspomaga biednych i bezdomnych, 10 proc. - ofiary klęsk żywiołowych, 6 proc. - chorych i niepełnosprawnych, 7 proc. - misje i organizacje religijne $)^{43}$.

${ }^{43}$ P. Aleksandrowicz, Dawanie jest przyjemne. Rozmowa z prof. Ryszardem Legutko, „Newsweek Polska” (2008) nr 1, s. 66-70. Por. W. Surmacz, Dobrze bogaci, „Newsweek Polska” (2008) nr 1, s. 70-74; R. Omachel, Powrót globalnego bankiera, „Newsweek Polska” (2009) nr 17, s. 56-60. 